\title{
ANALISIS KORELASI KEMAMPUAN BERPIKIR KREATIF MATEMATIK TERHADAP HASIL BELAJAR MATEMATIKA PESERTA DIDIK SMP NEGERI 3 LURANGUNG KUNINGAN JAWA BARAT
}

\author{
Oleh: \\ Ishaq Nuriadin ${ }^{1)}$ \\ Krisna Satrio Perbowo ${ }^{2)}$ \\ ${ }^{1}$ Pendidikan Matematika FKIP-UHAMKA, ishaq_nuriadin@yahoo.co.id \\ ${ }^{2}$ Pendidikan Matematika FKIP-UHAMKA, krisna_binsalam@yahoo.com
}

\begin{abstract}
Penelitian ini bertujuan untuk melihat korelasi antara kemampuan berpikir kreatif matematik dengan hasil belajar matematika peserta didik kelas VII SMP Negeri Luragung Kuningan Jawa Barat. Peserta didik diberikan tes kemampuan berpikir kreatif matematik dan test hasil belajar matematika. Populasi penelitian ini adalah siswa kelas VII SMP Negeri 3 Luragung, Kuningan, Jawa Barat, sedangkan sampel yang diambil adalah siswa kelas VIII A SMP Negeri 3 Luragung, Kuningan, Jawa Barat yang dipilih secara purposive sampling. Instrumen yang digunakan dalam penelitian ini adalah tes kemampuan berpikir kreatif matematik dan hasil belajar matematika. Setelah dilakukan analisis Varians didapat regresi linier dan pengujian keberartian regresi yang signifikan. Dari hasil perhitungan koefisien korelasi sebesar 0,559 dilanjutkan dengan uji t-student diperoleh 3,631. Hal ini berarti terdapat hubungan yang signifikan antara kemampuan berpikir kreatif matematik dengan hasil belajar matematika siswa dan kemampuan berpikir kreatif matematik memberikan kontribusi sebesar 31,2\% terhadap hasil belajar matematika siswa.
\end{abstract}

Kata Kunci : Kreatif, Hasil Belajar Matematika, Kemampuan Berpikir Kreatif Matematik.

This study aims to examine the correlations between mathematical creative thinking abilities with mathematics learning outcomes of students of class VII SMP Luragung Kuningan West Java . Learners are given tests of creative thinking skills test results to learn mathematics and mathematics . The study population was a class VII student of SMP Negeri 3 Luragung, Kuningan, West Java, while the samples taken are A class VIII student of SMP Negeri 3 Luragung, Kuningan, West Java, which is selected by purposive sampling . The instrument used in this study is a test of creative thinking skills and mathematical mathematics learning outcomes . After the analysis of variance and linear regression obtained significant regression significance testing . From the calculation of the correlation coefficient of 0.559 followed by Student 's t-test obtained 3.631. This means there is a significant relationship between mathematical creative thinking abilities with mathematics learning outcomes and mathematical creative thinking abilities contributed $31.2 \%$ of the students' mathematics learning outcomes.

Key words : Creative, Learning Outcomes Math, Creative Thinking Ability of Mathematical 


\section{Pendahuluan}

Tantangan masa depan yang selalu berubah sekaligus persaingan yang semakin ketat memerlukan pendidik yang tidak hanya terampil dalam suatu bidang tetapi juga kreatif dalam mengembangkan bidang yang ditekuni. Sehingga akan melahirkan siswa-siswa yang juga mampu untuk berpikir secara kreatif dalam menyelesaikan masalah. Hal tersebut perlu dimanifestasikan dalam setiap mata pelajaran di sekolah, termasuk matematika. Matematika sering dianggap sebagai ilmu yang hanya menekankan pada kemampuan berpikir logis dengan penyelesaian yang tunggal dan pasti. Hal ini yang menyebabkan matematika menjadi mata pelajaran yang ditakuti dan dijauhi siswa. Padahal, matematika dipelajari pada setiap jenjang pendidikan dan menjadi salah satu pengukur (indikator) keberhasilan siswa dalam menempuh suatu jenjang pendidikan, serta menjadi materi ujian untuk seleksi penerimaan menjadi tenaga kerja di bidang tertentu. Melihat kondisi ini berarti matematika tidak hanya digunakan sebagai acuan untuk melanjutkan pendidikan yang lebih tinggi saja tetapi juga digunakan dalam mendukung karir seseorang.

Mempelajari matematika, dapat dijadikan sebagai sarana untuk mengembangkan kemampuan berpikir dan menyelesaikan masalah perhitungan. Seperti ketika siswa melakukan operasi hitung pada bilangan pecahan. Mungkin orang dewasa akan dengan mudah menyatakan bahwa $1 / 4$ memiliki nilai yang sama dengan 0,25 , akan tetapi sebagian anak-anak terkadang mengalami kesulitan untuk memahami bahwa kedua nilai tersebut sebenarnya memiliki nilai yang sama.

Sampai saat ini, hanya sedikit orang yang memahami pentingnya belajar matematika. Untuk mengatasi hal ini maka dibuatlah berbagai macam metode baru dalam pengajaran matematika. Guru dituntut untuk lebih kreatif dan inovatif dalam mengajarkan pelajaran matematika kepada siswa, sehingga matematika dapat lebih menyenangkan dan menarik untuk dipelajari. Namun, pada kenyataannya sebagian guru matematika lebih sering menggunakan metode-metode lama dalam pengajarannya, seperti konsep algoritma yang digunakan dalam menyelesaikan perhitungan. Misalnya, ketika siswa diberikan soal penjumlahan antara 429 dan 14 . Jika menggunakan konsep algoritma, maka siswa akan menjumlahkan satuan terlebih dahulu dan dilanjutkan dengan menjumlahkan puluhannya dan terakhir pada ratusannya.

Seiring dengan perkembangan konsep perhitungan dalam matematika, tidak sedikit orang yang menganggap konsep algoritma sudah tidak sesuai. Pada umumnya, mereka para guru yang lebih tertarik pada metode-metode dan konsep-konsep baru. Penggunaan waktu yang cukup lama, proses perhitungan yang terkesan kaku dan sistematis yang dapat 'membunuh' kreatifitas siswa menjadi alasan mengapa konsep algoritma sudah jarang digunakan lagi. Seperti ketika seorang siswa menyelesaikan penjumlahan 429 dengan 14, siswa dapat menyelesaikannya dengan cara menghitung maju atau mundur. Angka 429 tidak dijumlahkan dengan 14, tapi 
dengan 10. Karena perhitungan dengan angka 10 akan lebih mudah. Maka $429+10$ = 439, kemudian hasil ini ditambahkan 4 lagi. Jadi hasilnya 440, 441, 442, 443.

Berdasarkan uraian di atas, maka perlu dilakukan suatu analisis korelasi kemampuan berpikir kreatif matematik terhadap hasil belajar matematika peserta didik. Penelitian ini dilakukan untuk melihat hubungan Kemampuan Berpikir Kreatif Matematik Terhadap Hasil Belajar Matematika Peserta Didik SMP Negeri 3 Luragung Kuningan Jawa Barat.

Rumusan masalah yang akan dikaji dalam penelitian ini difokuskan dalam bentuk pertanyaan "apakah terdapat korelasi antara kemampuan berpikir kreatif matematik dengan hasil belajar matematika peserta didik?". Sedangkan, hipotesis penelitian ini, yaitu Terdapat korelasi antara kemampuan berpikir kreatif matematik dengan hasil belajar matematika peserta didik.

\section{Telaah Kepustakaan}

\section{Kemampuan Berpikir Kreatif Matematik}

Berpikir merupakan suatu kemampuan mental yang ada dalam setiap individu. Kecakapan berpikir pada dasarnya merupakan kecakapan menggunakan pikiran atau rasio kita secara optimal. Kecakapan berpikir mencakup antara lain kecakapan menggali dan menemukan informasi (information searching) dan mengambil keputusan secara cerdas (information processing and decision making skills), serta kecakapan memacahkan masalah secara arif dan kreatif (creative problem solving).

Kreatifitas bukanlah suatu kata-kata mutiara yang eksklusif untuk sesuatu yang asing bagi manusia, kreatifitas justru merupakan suatu sisi dari manusia yang menandai "manusianya" seseorang. Karena dengan kreatifitas inilah manusia dapat berada pada kemajuan di beberapa bidang kehidupan. Seperti yang sering diungkapkan para pakar, setiap orang adalah kreatif walaupun dengan tingkat yang berbeda atau dengan cara pengekspresian yang berbeda.

Buzan $(2004,4)$ dalam bukunya The Power of Creative Intelligence Sepuluh Cara Jadi Orang yang Jenius Kreatif menjelaskan pengertian dari Creative Intelligence atau Kecerdasan Kreatif. Creative Intelligence (Kecerdasan Kreatif) adalah kemampuan kita memunculan ide-ide baru, menyelesaikan masalah dengan cara yang khas, dan untuk lebih meningkatkan imajinasi, prilaku, dan produktivitas kita.

Creative Intelligence melibatkan sejumlah faktor, dan semuanya bisa dipelajari dan dikembangkan sehingga kita dapat meningkatkan kreatifitas. Faktor-faktor tersebut antara lain (1) Keterampilan seseorang dalam menggunakan serta mengembangkan otak kira atau otak kanan mereka sehingga keduanya bisa saling bekerja sama dalam mengatasi suatu permasalahan, (2) Mind Mapping atau membuat catatan tentang apa yang kita pikirkan sehingga pikiran kita bisa lebih terlihat dan dapat lebih mudah 
untuk menjelajahinya dengan lebih cermat, (3) Kelancaran. Kecepatan mengeluarkan gagasan baru. Kelancaran merupakan ukuran produktivitas kreatif, (4) Fleksibilitas. Kemampuan untuk memproduksi berbagai gagasan, kemudian beralih sari satu cara ke cara lain dengan menggunakan berbagai strategi, (5) Orisinalitas. Keaslian atau orisinalitas memperlihatkan kemampuan untuk menghasilkan gagasan yang kita miliki yang tidak biasa, unik yang harfiahnya "jauh dari pusat", (6) Pengembangan gagasan. Pemikir yang kreatif akan memegang gagasan pokok yang kemudian dijadikan sebagai dasar untuk mengembangkan, memperluas, merancang, dan biasanya akan menguraikan pemikiran yang asli secara terperinci.

Filsaime (2008) mengutip pendapat dari Torrance tentang perngertian berpikir kreatif dalam bukunya Menguak Rahasia Berpikir Kritis dan Kreatif bahwa berpikir kreatif adalah "Sebuah proses menjadi sensitif pada atau sadar akan masalahmasalah, kekurangan, dan celah-celah di dalam pengetahuan yang untuknya tidak ada solusi yang dipelajari; membawa serta informasi yang ada dari gudang memori atau sumber-sumber eksternal; mendefinisikan kesulitan atau mengidentifikasi unsur-unsur yang hilang; mencari solusi-solusi; menduga, menciptakan alternatifalternatif untuk menyelesaikan masalah, menguji kembali alternatif tersebut; menyempurnakannya dan akhirnya mengkomunikasikan hasil-hasilnya”.

Torrance memandang berpikir kreatif sebagai sebuah proses yang melibatkan unsur-unsur orisinalitas, kelancaran, fleksibilitas dan elaborasi. Sementara Gilford (2008) mendeskripsikan berpikir kreatif sebagai "berpikir divergen". Berpikir divergen adalah sebuah proses penciptaan banyak ide tentang suatu topik tertentu di dalam waktu yang pendek. Berpikir divergen pada dasarnya terjadi secara spontan, dengan cara yang mengalir bebas. Ide-ide tersebut diciptakan dalam bentuk yang abstrak dan tidak terstruktur.

Gilford dan Torrance memiliki pandangan yang sama bahwa proses pengembangan berpikir kreatif memerlukan pengakuan terhadap kemampuan-kemampuan produksi divergen. Dengan demikian dapat disimpulkan bahwa berpikir kreatif merupakan suatu proses yang melibatkan unsur-unsur orisinalitas (originality), kelancaran (fluency), fleksibilitas (flexibility), dan elaborasi (elaboration).

Kemampuan berpikir kreatif merupakan kemampuan seseorang dalam menemukan gagasan atau ide baru dalam memecahkan permasalahan dengan menggunakan pengalaman sebelumnya yang telah mereka miliki.Pada dasarnya para ahli memliki pandangan yang sama tentang karakteristik dari kemampuan berpikir kreatif. Namun, untuk memberikan kejelasan dan pemahaman yang sesuai, maka peneliti akan memaparkan empat karakteristik umum yang nantinya akan menjadi indikator yang akan digunakan dalam penelitian ini, antara lain: 
1) Keterampilan berpikir lancar (Fluency)

Keterampilan berpikir lancar (fluency) di sini termasuk dalam mencetuskan banyak gagasan, jawaban, penyelesaian masalah atau pertanyaan. Memberikan banyak cara atau saran untuk melakukan berbagai hal serta selalu memikirkan lebih dari satu jawaban. Ini mungkin merupakan salah satu indikator yang paling kuat dari berpikir kreatif, karena semakin banyak ide, maka semakin besar kemungkinan yang ada untuk memperoleh sebuah ide yang signifikan.

2) Keterampilan berpikir luwes (Flexibility)

Fleksibilitas adalah kemampuan untuk mengatasi rintangan-rintangan mental, mengubah pendekatan untuk sebuah masalah. Tidak terjebak dengan mengasumsikan aturan-aturan atau kondisi-kondisi yang tidak bisa diterapkan pada sebuah masalah. Sehingga siswa dapat menerapkan suatu konsep atau suatu asas dengan cara yang berbeda-beda.

3) Keterampilan berpikir orisinil (Originality)

Katagori orisinalitas mengacu pada keunikan dari respon apa pun yang diberikan. Orisinalitas yang ditunjukkan oleh sebuah respon yang tidak biasa, unik dan jarang terjadi sehingga mampu membuat kombinasi-kombinasi yang tidak lazim dari bagian-bagian atau unsur-unsur.

4) Keterampilan merinci (Elaboration)

Kemampuan untuk menguraikan sebuah objek, gagasan, atau situasi tertentu secara mendetail sehingga menjadi sesuatu yang lebih menarik.

Berdasarkan pada uraian-uraian yang telah dikemukakan di atas, maka dapat dirumuskan bahwa pengertian kemampuan berpikir kreatif merupakan kemampuan berpikir yang sifatnya baru yang diperoleh dengan mencoba-coba dan ditandai dengan keterampilan berpikir lancar, luwes, orisinal, dan elaborasi.

\section{Hasil Belajar Matematika}

\section{Teori Belajar}

Belajar merupakan hakikat utama dalam proses pendidikan. Hal ini berarti bahwa keberhasilan pendidikan banyak bergantung pada proses belajar mengajar atau kegiatan pembelajaran. Seluruh manusia mengalami kegiatan yang dinamakan belajar, baik dia mengenyam pendidikan sekolah maupun yang tidak, baik yang buta maupun yang melihat, baik yang tuli maupun yang mendengar, dan sebagainya. Karena belajar tidak hanya berlangsung di sekolah saja namun berlangsung dalam kehidupan sehari-hari.

Seseorang dikatakan belajar bila terjadi proses perubahan tingkah laku, dimana perubahan tersebut relatif tetap. Seseorang tidak dikatakan belajar apabila tidak terjadi perubahan di dalam dirinya. Seperti yang dikemukakan oleh Kimble yang 
dikutip Simanjuntak (1993), bahwa "belajar adalah perubahan yang relatif menetap dalam potensi tingkah laku yang terjadi sebagai akibat dari latihan dengan penguatan dan tidak termasuk perubahan-perubahan karena kematangan, kelelahan atau kerusakan pada susunan saraf, atau memahami sesuatu sehingga terjadi perubahan dalam diri seseorang”.

Alwasilah (2003) memilih dua definisi belajar sebagai berikut: (1)"A relatively permanent change in response potentiality which occurs as a result of reinforced practice" dan (2)"a change in human disposition or capability, which can be retained, and which is not simply ascribable to the process of growth".

Dari definisi di atas yang harus diperhatikan sebagai proses belajar adalah menghasilkan perubahan perilaku anak didik yang relatif tetap, anak didik memiliki kemampuan dan potensi yang telah ada di dirinya untuk dikembangkan tanpa henti untuk mencapai keadaan ideal, dan perubahan atau perkembangan kemampuan atau potensi tersebut merupakan hasil bentukan bukan dihasilkan oleh pertambahan umur atau pertumbuhan badan.

\section{Teori Hasil Belajar}

Prestasi merupakan padanan kata dari hasil belajar yang bermakna hasil yang telah dicapai (dilakukan, dikerjakan) (Poerwadarminto, 1983). Sedangkan Lubis (1987) mengemukakan bahwa, hasil belajar berupa performance atau Achievement yaitu tingkah laku yang dinampakkan peserta didik sebagai hasil upaya mempelajari sesuatu.

Sesuai dengan tujuan belajar, maka kegiatan belajar yang terjadi menurut Bloom mencakup tiga kawasan perilaku yaitu kawasan kognitif, afektif, psikomotor (Winkel, 1984). Kawasan Kognitif berkenaan dengan aspek intelektual, dimana diterimanya pengetahuan oleh belajar sehingga terjadi perubahan dari tidak tahu menjadi tahu. Kawasan afektif berkenaan dengan minat dan sikap dimana terbentuknya minat dan sikap di dalam individu atas apa yang dipelajari. Dan kawasan psikomotor berkenaan dengan keterampilan bagi individu yang belajar sehingga terjadi perubahan pada diri individu tersebut.

Perubahan itulah yang disebut hasil belajar. Hasil belajar peserta didik pada hakekatnya adalah perubahan tingkah laku yang mencakup kemampuan kognitif, afektif dan psikomotor menjadi lebih baik." (Dimyati, 2002). Dan hasil belajar dapat dikatakan sebagai perubahan yang terjadi dalam diri individu akibat dari usaha yang dilakukan atau interaksi aktif individu dengan lingkungannya. Perubahan yang terjadi adalah perubahan secara menyeluruh, baik pengetahuan, sikap ataupun kebiasaannya. 
Berdasarkan uraian di atas maka hasil belajar yang dimaksud dalam penelitian ini adalah kemampuan menyelesaikan permasalahan yang berkaitan dengan matematika dan untuk berpikir matematis dalam kehidupan sehari-hari yang kemampuan tersebut didapat dari hasil pembelajaran.

\section{Metode Penelitian}

Metode yang digunakan dalam penelitian adalah metode survey dengan teknik korelasi. Dalam penelitian ini diperlukan 1 kelompok, dimana setiap responden dalam kelompok tersebut diberikan 2 perlakuan. Pada perlakuan pertama, responden diberikan tes untuk mengukur kemampuan berpikir kreatif matematik peserta didik (X) dan pada perlakuan kedua responden diberikan tes untuk mengukur hasil belajar matematika pada pokok bahasan bilangan pecahan $(\mathrm{Y})$.

Penelitian ini dilaksanakan di SMP Negeri 3 Luragung, Kuningan, yang beralamat di jalan Abdi Praja No. 1, Gunung Karung, Kecamatan Luragung, Kuningan. Sedangkan uji coba instrumen penelitian dilaksanakan di SMP Negeri 11, yang beralamat di jalan Kerinci VII Blok E, Kebayoran Baru, Jakarta Selatan. Populasi dalam penelitian ini adalah seluruh peserta didik kelas VII di SMPN 3 Luragung yang terdaftar pada semester ganjil tahun ajaran 2013/2014. Penelitian sampel dapat dilaksanakan apabila keadaan subyek di dalam populasi benar-benar homogen. Sampel diambil dari populasi terjangkau. Teknik pengambilan sampel yang digunakan dalam penelitian ini adalah teknik acak kelas (random cluster sampling) dengan mengambil 31 peserta didik dari populasi terjangkau.

\section{Hasil Penelitian}

Berdasarkan hasil perhitungan pada lampiran, diperoleh persamaan regresi $\hat{Y}=\mathbf{1 2 , 6}+\mathbf{0 , 4 4 6 X}$. Artinya kemampuan berpikir kreatif matematik siswa berhubungan positif dengan hasil belajar matematika siswa. Persamaan regresi tersebut menunjukan bahwa setiap penambahan satu skor kemampuan berpikir kreatif matematik diikuti perubahan peningkatan hasil belajar matematika siswa sebesar $\mathbf{0 , 4 4 6}$ pada konstanta $\mathbf{1 2 , 6 0 0}$.

Selanjutnya dilakukan perhitungan analisis varians (ANAVA) untuk uji keberartian regresi di peroleh $F_{\text {hitung }}=13,201$ dan $F_{(0,95)(1,29)}=4,180$. Karena $F_{\text {hitung }}>F_{\text {tabel }}$ yaitu 13,201 > 4,180 maka model regresi signifikan. Hasil perhitungan uji kelinieran regresi didapat $F_{\text {hitung }}=0,949$ dan $F_{(0,95)(11 / 18)}=2,370$. Karena $F_{\text {hitung }}<F_{\text {tabel }}$ yaitu $0,949<2,370$ maka regresi linier. Adapun distribusi $f\left(F_{\text {tabel }}\right)$ dapat dilihat pada Tabel 1 berikutnya. 
Tabel 1.

Simpulan Keberartian regresi dan Linieritas regresi

\begin{tabular}{|c|c|c|c|}
\hline Banyaknya Sampel & $\boldsymbol{F}_{\text {hitung }}$ & $\boldsymbol{F}_{\text {tabel }}$ & Simpulan \\
\hline 31 & 13,201 & 4,180 & Signifikan \\
\hline 31 & 0,949 & 2,370 & Linear \\
\hline
\end{tabular}

Tabel 2.

Analisis Varians (ANAVA)

\begin{tabular}{|l|c|l|l|l|}
\hline Sumber Variasi & \multicolumn{1}{|c|}{ dk } & \multicolumn{1}{c|}{ JK } & \multicolumn{1}{c|}{ KT } & \multicolumn{1}{c|}{ F } \\
\hline \multicolumn{1}{|c|}{ Total } & 31 & \multicolumn{1}{|c|}{14757} & \multicolumn{1}{|c|}{14757} & \\
\hline Regresi (a) & 1 & 14351,258 & 14351,258 & \\
Regresi (b|a) & 1 & 126,732 & 126,732 & 13,201 \\
Residu & 29 & 278,41 & 9,6 & \\
\hline Tuna cocok & 11 & 102,2 & 9,29 & 0,949 \\
Kekeliruan & 18 & 176,21 & 9,789 & \\
\hline
\end{tabular}

Selanjutnya dengan menggunakan program Excel dapat dibuat grafik persamaan regresinya, yaitu:

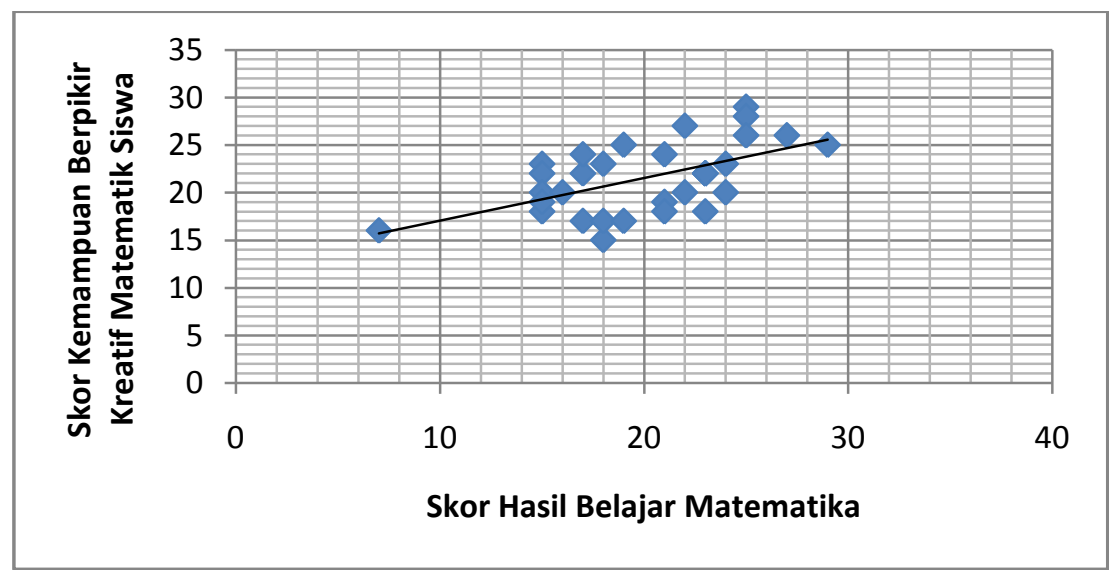

Gambar 1.

Grafik Persamaan Regresi Hubungan Kemampuan Berpikir Kreatif Matematik Dengan Hasil Belajar Matematika Siswa 


\section{Kesimpulan dan Saran}

Berdasarkan hasil analisis data dan pengujian hipotesis, maka dapat disimpulkan bahwa :

1. Terdapat hubungan yang positif antara kemampuan berpikir kreatif matematik dengan hasil belajar matematika siswa. Dengan diperoleh koefisien determinasi sebesar 0,312. Hal ini berarti bahwa kemampuan berpikir kreatif matematik memberikan kontribusi yang positif sebesar 31,2\% terhadap hasil belajar matematika siswa.

2. siswa yang memiliki kemampuan berpikir kreatif matematik dapat menyelesaikan masalah dari sudut pandang yang berbeda-beda. Mereka mampu menyelesaikan masalah dengan cara mereka sendiri, cara yang tidak menuntut untuk sesuai dengan algoritma yang diajarkan oleh kebanyakan guru di sekolah.

Sebagai implikasi dari kesimpulan tersebut di atas, pada kesempatan ini peneliti merasa perlu memberikan saran dengan harapan ada manfaatnya bagi perbaikan khususnya dalam bidang matematika sebagai berikut:

1. Bagi guru matematika

Dalam penelitian ini memberikan hasil suatu hubungan yang signifikan antara kemampuan berpikir kreatif matematik dengan hasil belajar matematika siswa, maka disarankan bagi para guru matematika hendaknya memberikan kebebasan kepada setiap siswa untuk dapat melakukan pendekatan terhadap ide, pemikiran, dan permasalahan terhadap suatu bilangan menurut caranya sendiri, karena setiap orang yang melakukan perhitungan matematika selalu dituntut untuk kreatif dan peka terhadap suatu bilangan.

2. Untuk Peneliti Selanjutnya

Bagi para peneliti yang berminat untuk melakukan penelitian selanjutnya, hendaknya dapat meneliti kontribusi kemampuan berpikir kreatif matematik terhadap kemampuan matematik yang lebih spesifik seperti kemampuan berpikir kritis, number sense, pemecahan masalah, dll. Karena dalam penelitian ini aspek hasil belajar matematika masih bersifat umum.

\section{DAFTAR PUSTAKA}

Adair, J. 2007. The Art of Creative Thinking. Britain: The Kogan Page Limited.

Arikunto, S. 2008. Dasar-dasar Evaluasi Pendidikan. Jakarta: Bumi Aksara.

Bresser, R dan Caren Holtzman. 1999. Developing Number Sense grade 3-6. California: Math Solutions Publications.

Buzan, T. 2004. The Power of Creative Intelligence Sepuluh Cara Jadi Orang yang Jenius Kreatif. (Jakarta: Gramedia Pustaka Utama).

Filsaime, D. 2008. Menguak Rahasia Berpikir Kritis dan Kreatif. Jakarta: Prestasi Pustaka. Marsigit. 2008.Matematika SMP Kelas VII. Jakarta: Yudistira. 
Munandar, U. 2009. Pengembangan Kreativitas Anak. Bandung: Rineka Cipta.

Ontario. 2006. Number sense and Numeration, Grades 4 to 6, Volume 5: Fractions. Ontario Education.

Ruseffendi, ET. 1988. Pengantar Kepada Membantu Guru Megembangkan Kompetensinya Dalam Pengajaran Matematika Untuk Meningkatkan CBSA. Bandung: Tarsito.

Sudjana. 1996. Metoda Statistik. Bandung: Tarsito.

Suherman, E. dkk. 1992. Strategi Belajar Mengajar Matematika. Jakarta: Universitas Terbuka.

Worthnington, M. 2006. Creativity Meets Mathematics. Practical Pre-School. 